\title{
PENGARUH KUALITAS DAN HARGA PERUMAHAN KOTA CITRA GRAHA TERHADAP MINAT BELI MASYARAKAT
}

\author{
Azahraty*, Abdul Kadir, MS*
}

Abstract,

The main objective in this study is to examine and analyze (1) the effect of quality and price. (4) To see which variable has greater influence

The targets in this study include (1) To be able to see how much influence the two variables in this study are quality and price. (2) Being a reference material for consumers to be able to determine the purchasing policy after knowing about the quality and price This research was conducted with a quantitative method and using the analysis method with SPSS Windows For Data as a data analysis tool. To facilitate the justification, a 5-point Likert scale is used. Likert scale is a scale used in questionnaires to facilitate respondents in answering questions, then respondents answer questions in accordance with the code in the questionnaire.

Based on the results of the study it can be found that the variable of quality and price is very significant in influencing the buying interest of consumers or prospective consumers to be able to purchase housing units in the City of Citra Graha, this can be proven with a probability level of more than 0.05 or less than 5\%. In addition to the level of probability can also be proven by table 5.8 it turns out that $F$ count is greater $(33,108)$ than $F$ table $(2.3092)$, so the decision is to reject $\mathrm{HO}$ and accept $\mathrm{Ha}$, which means the variables X1, X2 together affect the consumer's buying interest will the purchase of housing units in the City of Citra Graha. Job Characteristics Variable has a significant and positive effect on the level of employee job satisfaction with a significance level of 0.473 or $47.3 \%$. This means that if the characteristics of this work are considered it will increase employee job satisfaction by 47.3\%.

Keywords: Quality, Price, Interest.

*Universitas Islam Kalimantan Muhammad Arsyad Al-Banjary 


\section{LATAR BELAKANG}

Kebutuhan perumahan merupakan salah satu kebutuhan pokok masyarakat, selain sandang dan pangan. Perumahan dan pemukiman seperti telah digariskan oleh kebijaksanaan pemerintah bahwa pembangunan perumahan dan pemukiman diarahkan untuk meningkatkan kualitas kehidupan keluarga dan masyarakat, menciptakan kerukunan, serta kesetiakawanan sosial masyarakat. Seiring dengan perkembangan perekonomian, Kota Citra Graha terus menerus melakukan membangun perumahan-perumahan di daerah Banjarmasin terutama di wilayah kabupaten Banjar untuk mencari konsumen. Kondisi seperti itulah yang pada akhirnya menyebabkan para pelaku usaha makin gencar berusaha untuk mencari solusi maupun program bisnis yang dapat meningkatkan daya saing perusahaan di dalam bisnisnya. Namun demikian, meskipun Kota Citra Graha telah berusaha bersaing dan memberikan yang terbaik untuk konsumen belum tentu dapat menjamin akan berhasilnya usaha pencapaian tujuan perusahaan. Sering kali Kota Citra Graha menemukan masalah dalam promosi, di mana konsumen melihat kualitas serta harga yang mahal sehingga mempengaruhi minat beli masyarakat.

Perilaku pembelian seseorang dapat dikatakan sesuatu yang unik, karena preferensi dan sikap terhadap obyek setiap orang berbeda. Selain itu masyarakat berasal dari bebagai segmen, sehingga apa yang diinginkan dan dibutuhkan juga berbeda. Produsen perlu memamahi perilaku konsumen terhadap produk yang ditawarkan dan dipasaran. Perilaku pembelian seseorang dapat dikatakan sesuatu yang unik, karena preferensi dan sikap terhadap obyek setiap orang yang berbeda. Selain itu masyarakat berasal dari berbagai segmen, sehingga apa yang diinginkan dan dibutuhkan juga berbeda. Masih banyak faktor yang berpengaruh terhadap minat beli masyarakat. Produsen perlu memahami perilaku konsumen terhadap produk yang ada di pasar. Selanjutnya perlu dilakukan berbagai cara untuk membuat konsumen tertarik terhadap produk yang dihasilkan.

Menghadapi semakin ketatnya persaingan bisnis khususnya dibidang perumahan, maka untuk dapat memenangkan persaingan sekaligus agar dapat bertahan Kota Citra Graha perlu melakukan berbagai strategi dalam menjalankan bisnisnya. Selain bentuk fisik yang menjadi pertimbangan ada beberapa pertimbangan lain yang tak kalah penting antara lain yaitu kualitas dan harga perunit perumahan. Harga merupakan satu-satunya unsur marketing mix yang menghasilkan penerimaan penjualan, sedangkan unsur lainnya hanya unsur biaya saja. Walaupun penetapan harga merupakan persoalan penting, masih banyak perusahaan yang kurang sempurna dalam menangani permasalahan penetapan harga tersebut. Karena menghasilkan penerimaan penjualan, maka harga mempengaruhi tingkat penjualan, tingkat keuntungan, serta share pasar yang dapat dicapai oleh perusahaan. Kotler, terjemahan (2008) mengemukakan bahwa harga merupakan satusatunya elemen bauran pemasaran yang menghasilkan pendapatan, elemen-elemen lainnya menimbulkan biaya. Harga juga merupakan salah satu elemen bauran pemasaran yang paling fleksibel. Harga dapat diubah dengan cepat, tidak seperti ciri khas (feature) produk dan perjanjian distribusi. Pada saat yang sama, penetapan dan persaingan harga juga merupakan masalah nomor satu yang dihadapi perusahaan.

\section{KAJIAN LITERATUR}

Kualitas merupakan salah satu kunci dalam memenangkan persaingan dengan pasar. Ketika perusahaan telah mampu menyediakan produk berkualitas maka telah membangun salah satu fondasi untuk menciptakan kepuasan pelanggan. Menurut Goetsch dan Davis (1994) yang dikutip oleh Tjiptono (2012:152), kualitas dapat diartikan sebagai "kondisi dinamis yang berhubungan dengan produk, jasa, sumber daya manusia, 
proses, dan lingkungan yang memenuhi atau melebihi harapan". Berdasarkan definisi ini, kualitas adalah hubungan antara produk dan pelayanan atau jasa yang diberikan kepada konsumen dapat memenuhi harapan dan kepuasan konsumen.

Kualitas adalah kesesuaian dengan kebutuhan pasar atau konsumen. (Abubakar \& Siregar, $2010:$ p.2) Tjiptono dan Sunyoto (2012) mengatakan bahwa kualitas merupakan "sebuah kondisi dinamis yang berhubungan dengan produk, jasa, manusia, proses, dan lingkungan yang memenuhi atau melebihi harapan." Sunyoto (2012) menyatakan bahwa kualitas merupakan suatu ukuran untuk menilai bahwa suatu barang atau jasa telah mempunyai nilai guna seperti yang dikehendaki atau dengan kata lain suatu barang atau jasa dianggap telah memiliki kualitas apabila berfungsi atau mempunyai nilai guna seperti yang diinginkan.

Dari beberapa definisi tersebut dapat disimpulkan bahwa kualitas adalah unsur yang saling berhubungan mengenai mutu yang dapat mempengaruhi kinerja dalam memenuhi harapan pelanggan. Kualitas tidak hanya menekankan pada hasil akhir, yaitu produk dan jasa tetapi menyangkut kualitas manusia, kualitas proses, dan kualitas lingkungan. Dalam menghasilkan suatu produk dan jasa yang berkualitas melalui manusia dan proses yang berkualitas.

Perusahaan dapat meningkatkan pangsa pasarnya melalui pemenuhan kualitas yang bersifat customer - driven yang akan memberikan keunggulan harga dan customer value. Customer value merupakan kombinasi dari manfaat dan pengorbanan yang terjadi apabila pelanggan menggunakan suatu barang atau jasa guna memenuhi kebutuhan tertentu. Jika kualitas yang dihasilkan superior dan pangsa pasar yang dimiliki besar, maka profitabilitasnya terjamin. Manfaat superior meliputi: a. Loyalitas pelanggan yang besar

b. Pangsa pasar lebih besar

c. Harga saham yang lebih tinggi

d. Harga jual produk / jasa lebih tinggi

e. Produk vitas yang lebih besar Stanton (2004) berpendapat bahwa ada beberapa faktor yang biasanya mempengaruhi keputusan penentapan harga, antara lain:

a. Permintaan produk. Memperkirakan permintaan total terhadap produk adalah langkah yang penting dalam penetapan harga sebuah produk. Ada dua langkah yang dapat dilakukan dalam memperkirakan permintaan produk, yaitu menentukan apakah ada harga tertentu yang diharapkan oleh pasar dan memperkirakan volume penjualan atas dasar harga yang berbeda-beda.

b. Target pangsa pasar. Perusahaan yang berupaya meningkatkan pangsa pasarnya bisa menetapkan harga dengan lebih agresif dengan harga yang lebih rendah dibandingkan perusahaan lain yang hanya ingin mempertahankan pangsa pasarnya. Pangsa pasar dipengaruhi oleh kapasitas produksi perusahaan dan kemudahan untuk masuk dalam persaingan pasar.

c. Reaksi pesaing. Adanya persaingan baik yang sudah ada maupun yang masih potensial, merupakan faktor yang mempunyai pengaruh penting dalam menetukan harga dasar suatu produk. Persaingan biasanya dipengaruhi oleh adanya produk serupa, produk pengganti atau substitusi, dan adanya produk yang tidak serupa namun mecari konsumen atau pangsa pasar yang sama.

d. Penggunaan strategi penetapan harga: penetrasi ratai saringan. Untuk produk baru, biasanya menggunakan strategi penetapan harga saringan. Strategi ini berupa penetapan harga yang tinggi dalam lingkup harga-harga yang diharapkan atau harga yang menjadi 
harapan konsumen. Sedangkan strategi berikutnya yaitu strategi penetapan harga penetrasi. Strategi ini menetapkan harga awal yang rendah untuk suatu produk dengan tujuan memperoleh konsumen dalam jumlah banyak dan dalam waktu yang cepat.

e. Produk, saluran distribusi dan promosi

Untuk beberapa jenis produk, konsumen lebih memilih membeli produk dengan harga yang lebih murah dengan kualitas dan kriteria yang mereka perlukan. Sebuah perusahaan yang menjual produknya langsung kepada konsumen dan melalui distribusi melakukan penetapan harga yang berbeda. Sedangkan untuk promosi, harga produk akan lebih murah apabila biaya promosi produk tidak hanya dibebankan kepada perusahaan, tetapi juga kepada pengecer.

f. Biaya memproduksi atau membeli produk. Seorang pengusaha perlu mempertimbangkan biaya-biaya dalam produksi dan perubahan yang terjadi dalam kuantitasproduksi apabila ingin dapat menetapkan harga secara efektif.

Menurut Kotler dan Keller (2003: 186), the consumer may also form an intention to buy the most preffered brand yang berarti bahwa konsumen mempunyai keinginan untuk membeli suatu produk berdasarkan pada sebuah merek. Menurut Kotler, Bowen, \& Makens (1999: 156), mengenai minat beli : minat beli timbul setelah adanya proses evaluasi alternatif dan di dalam proses evaluasi, seseorang akan membuat suatu rangkaian pilihan mengenai produk yang hendak dibeli atas dasar merek maupun minat.

Swastha \& Irawan (2001)

mengemukakan faktor-faktor yang mempengaruhi minat membeli yang berhubung dengan perasaan dan emosi, bila seseorang merasa senang dan puas dalam membeli barang atau jasa maka hal itu akan memperkuat minat membeli, ketidakpuasan biasanya menghilangkan minat. Super \& Crites (Lidyawatie, 1998) menjelaskan bahwa ada beberapa faktor yang mempengaruhi minat, yaitu :

a. Perbedaan pekerjaan, artinya dengan adanya perbedaan pekerjaan seseorang dapat diperkirakan minat terhadap tingkat pekerjaan yang ingin dicapainya, aktivitas yang dilakukan, penggunaan waktusenggangnya, dan lain-lain.

b. Perbedaan sosial ekonomi, artinya seseorang yang mempunyai sosial ekonomni tinggi akan lebih mudah mencapai apa yang diinginkannya daripada yang mempunyai sosial ekonomi rendah.

c. Perbedaan hobi atau kegemaran, artinya bagaimana seseorang menggunakan waktu senggangnya.

d. Perbedaan jenis kelamin, artinya usia anak-anak, remaja, dewasa dan orang tua akan berbeda minatnya terhadap suatu barang, aktivitas benda dan seseorang.

Menurut Mowen (2002) bahwa, "perilaku konsumen (consumer behaviour) didefinisikan sebagai studi tentang unit pembelian (buying units) dan proses pertukaran yang melibatkan perolehan, konsumsi dan pembuangan barang, jasa, pengalaman serta ide-ide.

Sedangkan menurut Kotler (2007) bahwa, "perilaku konsumen merupakan studi tentang cara individu, kelompok, dan organisasi menyeleksi, membeli, menggunakan, dan memposisikan barang, jasa, gagasan, atau pengalaman untuk memuaskan kebutuhan dan keinginan mereka". Peter dan Olson (1999) dalam Simamora (2003) menyatakan bahwa perilaku konsumen adalah soal keputusan. Lebih jauh lagi, keputusan adalah soal pilihan. Untuk lebih jelasnya mereka menyatakan bahwa keputusan meliputi suatu pilihan "antara dua atau lebih alternatif tindakan atau perilaku". Sastradipora (2003) 
menyatakan bahwa: "perilaku konsumen adalah proses dimana para individu menetapkan jawaban atas pertanyaan: perlukah, apakah, kapankah, dimanakah, bagaimanakah, dan dari siapakah membeli barang atau jasa".

Pemasaran yang diartikan kebanyakan orang mengatakan bahwa pemasaran berarti menjual atau memasang iklan. Dan bahkan ada pula yang mengatakan bahwa pemasaran sama halnya dengan melakukan kegiatan distribusi, promosi dan sebagainya, tetapi semua hal-hal diatas pada dasarnya belum mendekati sebagaimana yang diinginkan. Namun, adalah sangat penting untuk di ketahui, bahwa menjual, memasang iklan dan melakukan kegiatan distribusi hanya merupakan sebagian dari kegiatan pemasaran, karena kegiatan pemasaran meliputi kegiatan yang lebih dari hanya sekedar menjual dan memasang iklan.

Tjiptono (2005:2) mengemukakan bahwa pemasaran merupakan proses dimana struktur permintaan terhadap produk dan jasa diantisipasi atau diperluas dan dipuaskan melalui konsepsi, promosi, distribusi, dan pertukaran barang. Machfoedz (2010 : 140) mengemukakan bahwa pemasaran adalah suatu proses yang diterapkan perusahaan untuk memenuhi kebutuhan dan keinginan konsumen dengan menyediakan produk (barang dan jasa). Konsumen tertentu yang merupakan sasaran upaya pemasaran disebut pasar sasaran.

Tujuan pemasaran adalah mengenal dan memahami pelanggan sedemikian rupa, sehingga produk cocok dengannya dan dapat dijual dengan sendirinya, idealnya, pemasaran menyebabkan pelangan siap membeli, sehingga produsen harus berusaha agar produknya tetap tersedia.

Menurut Philip Kotler (2007:6) Tujuan pemasaran adalah menghasilkan standar hidup yang lebih tinggi agar konsumen memperoleh apa yang mereka butuhkan dan inginkan melalui penciptaan, menawarkan dan secara bebas mempertukarkan produk yang bernilai dengan pihak lain.

\section{METODE PENELITIAN}

jenis penelitian yang digunakan oleh peneliti adalah penelitian kuantitatif yaitu suatu model penelitian yang mengharuskan akan adanya perhitungan angka-angka, sedangkan pendekatan yang digunakan adalah dengan pendekatan survei yaitu penelitian yang mengambil sampel dari populasi dan menggunakan kuesioner sebagai alat pengumpulan data yang pokok Singarimbun (1989:3). Untuk memudahkan justifikasi digunakan skala Likert 5 poin. Skala Likert adalah skala yang digunakan dalam quesioner untuk mempermudah responden dalam menjawab pertanyaan, kemudian responden menjawab pertanyaan sesuai dengan kode yang ada dalam quesioner. Objek dalam penelitian ini adalah masyarakat atau konsumen yang akan melakukan pembelian perumahan di Kota Citra Graha.

Teknik sampel yang digunakan dalam penelita ini Accidental Random Sampling, pengambilan sampel secara acak terhadap responden yang paling mudah ditemui dan bersedia berpartisipasi dalam pengisian kuisioner.

Dalam rangka memperoleh data untuk penelitian ini digunakan teknik pengumpulan data adalah :

1. Observasi

2. Dokumentasi

3. Kuisioner

Teknik analisis data yang digunakan dalam penelitian ini menggunakan regresi linear berganda. Sebelum dilakukan pengujian dengan analisis regresi, data penelitian diuji dengan uji asumsi klasik yang terdiri dari : uji normalitas, uji heterokedastisitas, dan uji multikolonieritas. Kemudian untuk pengujian hipotesis secara simultan menggunakan Uji F, dan untuk 
pengujian hipotesis secara parsial menggunakan Uji t. Sedangkan untuk menentukan variabel yang paling dominan mempengaruhi tingkat kepuasan kerja karyawan menggunakan nilai standrdized coefficient beta.

\section{HASIL PENELITIAN PEMBAHASAN}

DAN

Penelitian ini dilakukan pada seluruh Konsumen dan calon konsumen (pembeli) pada perumahan Kota Citra Graha dengan jumlah populasi responden sebanyak 100 orang. Sebelum melakukan penyebaran kuisioner secara luas, maka terlebih dahulu dilakukan uji Validitas dan Reliabelitas atas instrumen penelitian yang akan digunakan, dalam hal ini kuisioner yang telah disusun. Uji validitas dengan metode ini, merupakan uji validitas item, dasar kerjanya dengan komputasi korelasi antar setiap item dengan skor total tes sebagai kriteria validitasnya. Adapun hasil yang diperoleh dari uji validitas kuisioner yang dilakukan terhadap responden seperti pada tabel dibawah ini.

Tabel 1 Ringkasan Hasil Tes Validitas Kuisioner

\begin{tabular}{|c|c|c|c|c|}
\hline Variabel & $\begin{array}{c}\text { Butir } \\
\text { pertanyaan }\end{array}$ & $\mathrm{r}$ & $\mathrm{p}$ & Status \\
\hline \multirow{3}{*}{$\begin{array}{c}\text { Kualitas } \\
(\mathrm{X} 1)\end{array}$} & $\mathrm{X} 1.1$ & .738 & 0,000 & Valid \\
\cline { 2 - 5 } & $\mathrm{X} 1.2$ & .498 & 0,000 & Valid \\
\cline { 2 - 5 } & $\mathrm{X} 1.3$ & .698 & 0,000 & Valid \\
\hline \multirow{3}{*}{ Harga (X2) } & $\mathrm{X} 2.1$ & .726 & 0,000 & Valid \\
\cline { 2 - 5 } & $\mathrm{X} 2.2$ & .658 & 0,000 & Valid \\
\cline { 2 - 5 } & $\mathrm{X} 2.3$ & .786 & 0,000 & Valid \\
\hline \multirow{3}{*}{$\begin{array}{c}\text { Minat Beli } \\
(\mathrm{Y})\end{array}$} & $\mathrm{Y} 1.1$ & .671 & 0,000 & Valid \\
\cline { 2 - 5 } & $\mathrm{Y} 1.2$ & .707 & 0,000 & Valid \\
\cline { 2 - 5 } & $\mathrm{Y} 1.3$ & .831 & 0,000 & Valid \\
\hline
\end{tabular}

Sumber: Data Primer yang sudah diolah 2020.

Berdasarkan dari uji validitas menunjuksn bahwa niloi $\mathrm{r}_{\text {hitung }}$ Lebih besar dari $r_{\text {tabel }}$ dengan hasil ini maka kuisioner yang digunakan oleh variabel X1 dan X2 dinyatakan valid sebagai alat ukur variabel.
Tabel 2 Hasil Uji Reliabilitas

\begin{tabular}{|l|c|c|c|c|}
\hline Variabel & $\begin{array}{c}\text { Hasil } \\
\text { Cronbac } \\
\text { h's Alpha }\end{array}$ & $\longleftrightarrow$ & $\begin{array}{c}\text { Standar } \\
\text { Reliabil } \\
\text { itas }\end{array}$ & $\begin{array}{c}\text { Keter } \\
\text { angan }\end{array}$ \\
\hline $\begin{array}{l}\text { Kualitas } \\
\text { X1) }\end{array}$ & .668 & $>$ & 0.60 & $\begin{array}{c}\text { Relia } \\
\text { bel }\end{array}$ \\
\hline $\begin{array}{l}\text { Harga } \\
\text { (X2) }\end{array}$ & .782 & $>$ & 0.60 & $\begin{array}{c}\text { Relia } \\
\text { bel }\end{array}$ \\
\hline
\end{tabular}

Sumber: Data Primer yang sudah diolah 2020.

Hasil pada tabel diatas menunjukan bahwa alpha yang distandardisasi untuk semua variabel $\mathrm{X}$ dan $\mathrm{Y}$ mempunyai nilai yang lebih besar dari 0,5 dengan demikian maka item-item pertanyaan seluruhnya bisa dianggap reliabel dalam melakukan fungsinya sebagai alat ukur.

Langkah selanjutnya adalah melakukan uji asumsi klasik, dengan urutan pengujian sebagai berikut:

\section{Linieritas}

Pengujian linieritas dalam penelitian ini menggunakan dilakukan dengan analisis grafik Normal P.P of Regression Standardized Residual. Jika terdapat gejala bahwa letak gejala titiktitik (data) itu ada pada atau menyebar sekitar garis lurus diagonalnya, maka cukup menjadi alasan bahwa antara variabel-variabel tersebut terdapat hubungan linier. Hasil uji linieritas pada penelitian ini dapat dilihat pada grafik berikut:

\section{Gambar Grafik Hasil Uji Linieritas}

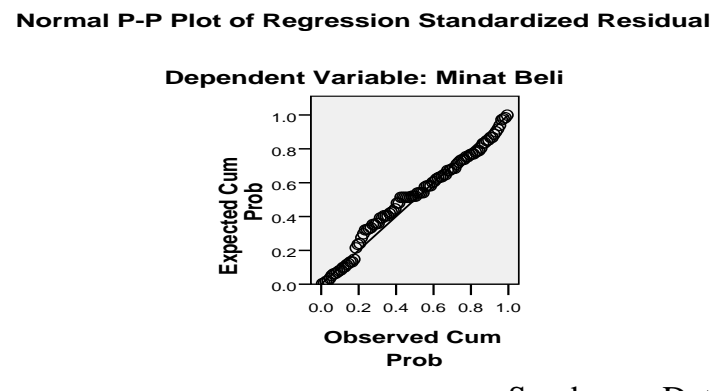

Primer Yang Diolah 2020.

Sumber: Data

Berdasarkan grafik diatas maka dapat disimpulkan bahwa plot data 
menyebar sekitar garis lurus mengikuti garis diagonalnya. Dengan demikian dapat diartikan bahwa terdapat adanya hubungan linier antara variabel-variabel bebas dengan variabel terikat.

\section{Uji Multikolinearitas}

Hasil uji multikolinearitas dapat ditampilkan dalam tabel berikut:

Tabel 3 Hasil Uji Multikolinieritas

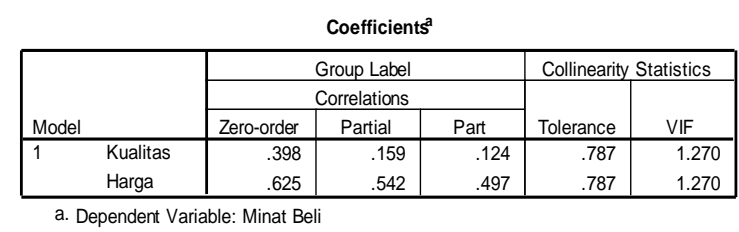

Sumber: Data yang diolah tahun 2020.

Berdasarkan tabel diatas, maka dapat disimpulkan bahwa variabel yang mempengaruhi minat beli konsumen atau calon konsumen terhadap perumahan di Kota Citra Graha terutama variabel kualitas (X1) memiliki nilai toleransi 0.787 dengan VIF sebesar 1.270, Variavel Harga (X2) juga memiliki nilai Tolerance dan nilai VIF yang sama yakni Toleransi sebesar 0.787 dan nilai VIF sebesar 1.270. Dengan demikian, dapat disimpulkan bahwa kedua variabel memiliki nilai VIF kurang dari 10 dan nilai tolerance diatas 0,1 maka dapat disimpulkan tidak terjadi multikolinieritas.

\section{Uji Regresi Linier Berganda}

Analisis ini digunakan untuk mengetahui atau meramalkan besarnya pengaruh kualitas dan harga dalam mempengaruhi minat beli konsumen atau calon konsumen untuk melakukan pembelian unit perumahan di Kota Citra Graha. Dari hasil pengolahan data dengan komputer diperoleh koefisien regresi seperti dalam tabel berikut:

\section{Tabel 4 Koefisien Regresi Linear} Berganda

\begin{tabular}{|c|c|c|c|c|c|c|}
\hline \multicolumn{7}{|c|}{ Coefficients $^{\mathrm{a}}$} \\
\hline \multirow[b]{2}{*}{ Mod } & & \multicolumn{2}{|c|}{$\begin{array}{l}\text { Unstandardized } \\
\text { Coefficients }\end{array}$} & \multirow{2}{*}{$\begin{array}{c}\text { Standardized } \\
\text { Coefficients } \\
\text { Beta }\end{array}$} & \multirow[b]{2}{*}{$t$} & \multirow[b]{2}{*}{ Sig. } \\
\hline & & B & Std. Error & & & \\
\hline \multirow[t]{3}{*}{1} & (Constant) & 1.037 & .356 & & 2.910 & .004 \\
\hline & Kualitas & .147 & .092 & .140 & 1.590 & .115 \\
\hline & Harga & .589 & .093 & .560 & 6.348 & .000 \\
\hline
\end{tabular}

Sumber: Data Primer yang sudah diolah 2020.

Dari tabel diatas, maka persamaan Regresi yang terbentuk adalah sebagai berikut: $\mathbf{Y}=\mathbf{1 . 0 3 7}+\mathbf{0 . 1 4 7} \mathrm{X} 1+\mathbf{0 . 5 8 9} \mathrm{X} 2$ + e. Hasil dari analisis tersebut dapat diinterprestasikan sebagai berikut: 1.037, artinya bahwa variabel yang mempengaruhi terhadap minat beli konsumen akan pembelian unit perumahan di Kota Citra Graha sama dengan nol maka minat beli akan naik sebesar 1.037 satuan atau naik sebesar 10.37\%. 0.147, artinya bahwa apabila variabel kualitas (X1) yang mempengaruhi terhadap minat beli konsumen akan pembelian unit perumahan di Kota Citra Graha, maka maka rata-rata minatnya akan naik sebesar 0.147 satuan atau hanya akan berpengaruh sebesar $14.7 \%$, sedangkan variabel lain konstan. 0,589, artinya bahwa apabila variabel harga (X2) yang mempengaruhi terhadap minat beli konsumen akan pembelian unit perumahan di Kota Citra Graha, maka rata-rata minatnya akan naik sebesar 0,589 satuan atau sebesar 58.9\%, sedangkan variabel lain konstan. 
Tabel 5 Hasil Uji t

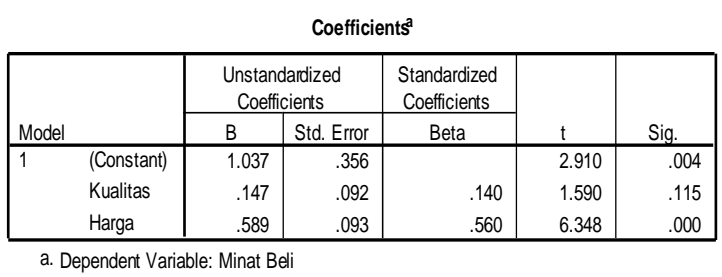

Dari hasil rangkuman nilai $\mathrm{T}$ signifikan pada tabel diatas terlihat bahwa, Variabel X1 (Kualitas) nilai signifikan $\mathrm{T}$ lebih besar dari $5 \%$ yaitu 1.590 dengan angka sig 0.115. Untuk Variabel X2 (Harga) nilai signifikan $\mathrm{T}$ lebih besar dari 5\% yaitu 6.348 dengan angka sig. 0.000. Jadi variabel $\mathrm{X} 1$ dan $\mathrm{X} 2$ signifikan dalam mempengaruhi $\mathrm{Y}$ (Minat) atau $\mathrm{H}_{0}$ ditolak dan $\mathrm{H}_{\mathrm{a}}$ diterima.

\section{Pembahasan Hasil Penelitian}

1. Tingkat Pengaruh Variabel Kualitas Dan Harga Dalam Mempengaruhi Minat Beli Konsumen.

Kualitas adalah unsur yang saling berhubungan mengenai mutu yang dapat mempengaruhi kinerja dalam memenuhi harapan pelanggan. Kualitas tidak hanya menekankan pada hasil akhir, yaitu produk dan jasa tetapi menyangkut kualitas manusia, kualitas proses, dan kualitas lingkungan. Dalam menghasilkan suatu produk dan jasa yang berkualitas melalui manusia dan proses yang berkualitas. Sunyoto (2012) menyatakan bahwa kualitas merupakan suatu ukuran untuk menilai bahwa suatu barang atau jasa telah mempunyai nilai guna seperti yang dikehendaki atau dengan kata lain suatu barang atau jasa dianggap telah memiliki kualitas apabila berfungsi atau mempunyai nilai guna seperti yang diinginkan.

Menurut Stanton (2004:306) harga pasar sebuah produk mempengaruhi upah, sewa, bunga, dan laba. Artinya, harga produk mempengaruhi biaya faktor-faktor produksi (tenaga kerja, tanah, modal, dan kewiraswastaan. Sehingga definisi harga adalah alat pengukur dasar sebuah sistem ekonomi karena harga mempengaruhi alokasi faktor-faktor produksi. Dan harga juga dapat didefinisikan sebagai jumlah uang yang dibutuhkan untuk memperoleh beberapa kombinasi sebuah produk dan pelayanan yang menyertainya. Dalam menghadapi persaingan, perusahaan perlu lebih bijaksana dalam menentukan harga produknya. Banyak hal-hal yang harus dipertimbangkan oleh pengusaha sebelum menetapkan harga suatu produk.

Dalam penelitian ini menunjukan bahwa variabel kualitas dan harga sangat signifikan dalam mempengaruhi minat beli konsumen atau calon konsumen untuk dapat melakukan pembelian unit perumahan di Kota Citra Graha, hal ini dapat dibuktikan dengan tingkat probabilitas lebih dari 0,05 atau kurang dari 5\%. Selain tingkat probabilitas juga dapat dibuktikan dengan tabel 5.8 ternyata F hitung lebih besar (33.108) dari $F$ tabel (2,3092), sehingga keputusannya adalah menolak $\mathrm{H}_{0}$ dan menerima $\mathrm{H}_{\mathrm{a}}$ yang artinya variabel $\mathrm{X} 1$, $\mathrm{X} 2$ secara bersama-sama berpengaruh pada minat beli konsumen akan pembelian unit perumahan di Kota Citra Graha.

2. Tingkat Pengaruh Kualitas Terhadap Minat Beli Konsumen Perumahan Kota Citra Graha

Kualitas merupakan salah satu kunci dalam memenangkan persaingan dengan pasar. Ketika perusahaan telah mampu menyediakan produk berkualitas maka telah membangun salah satu fondasi untuk menciptakan kepuasan pelanggan. Menurut Goetsch dan Davis (1994) yang dikutip oleh Tjiptono 
(2012:152), kualitas dapat diartikan sebagai "kondisi dinamis yang berhubungan dengan produk, jasa, sumber daya manusia, proses, dan lingkungan yang memenuhi atau melebihi harapan". Berdasarkan definisi ini, kualitas adalah hubungan antara produk dan pelayanan atau jasa yang diberikan kepada konsumen dapat memenuhi harapan dan kepuasan konsumen.

Dalam penelitian ini menunjukan bahwa variabel kualitas berpengaruh positif dan signifikan dalam mempengaruhi minat beli konsumen atau calon konsumen untuk dapat melakukan pembelian unit perumahan di Kota Citra Graha, hal ini dapat dibuktikan dengan tingkat probabilitas lebih dari 0,05 atau kurang dari 5\%. Dari hasil rangkuman nilai $\mathrm{T}$ signifikan pada tabel 5.9 terlihat bahwa, Variabel X1 (Kualitas) nilai signifikan $\mathrm{T}$ lebih besar dari $5 \%$ yaitu 1.590 dengan angka sig 0.115 .

3. Tingkat Pengaruh Harga Terhadap Minat Beli Konsumen Perumahan Kota Citra Graha

Stanton (2004) berpendapat bahwa ada beberapa faktor yang biasanya mempengaruhi keputusan penentapan harga, antara lain:

a. Permintaan produk . Memperkirakan permintaan total terhadap produk adalah langkah yang penting dalam penetapan harga sebuah produk. Ada dua langkah yang dapat dilakukan dalam memperkirakan permintaan produk, yaitu menentukan apakah ada harga tertentu yang diharapkan oleh pasar dan memperkirakan volume penjualan atas dasar harga yang berbeda-beda.

b. Target pangsa pasar. Perusahaan yang berupaya meningkatkan pangsa pasarnya bisa menetapkan harga dengan lebih agresif dengan harga yang lebih rendah dibandingkan perusahaan lain yang hanya ingin mempertahankan pangsa pasarnya. Pangsa pasar dipengaruhi oleh kapasitas produksi perusahaan dan kemudahan untuk masuk dalam persaingan pasar.

c. Reaksi pesaing. Adanya persaingan baik yang sudah ada maupun yang masih potensial, merupakan faktor yang mempunyai pengaruh penting dalam menetukan harga dasar suatu produk. Persaingan biasanya dipengaruhi oleh adanya produk serupa, produk pengganti atau substitusi, dan adanya produk yang tidak serupa namun mecari konsumen atau pangsa pasar yang sama.

d. Penggunaan strategi penetapan harga: penetrasi rantai saringan. Untuk produk baru, biasanya menggunakan strategi penetapan harga saringan. Strategi ini berupa penetapan harga yang tinggi dalam lingkup harga-harga yang diharapkan atau harga yang menjadi harapan konsumen. Sedangkan strategi berikutnya yaitu strategi penetapan harga penetrasi. Strategi ini menetapkan harga awal yang rendah untuk suatu produk dengan tujuan memperoleh konsumen dalam jumlah banyak dan dalam waktu yang cepat.

e. Produk, saluran distribusi dan promosi. Untuk beberapa jenis produk, konsumen lebih memilih membeli produk dengan harga yang lebih murah dengan kualitas dan kriteria yang mereka perlukan. Sebuah perusahaan yang menjual produknya langsung kepada konsumen dan melalui distribusi melakukan penetapan harga yang berbeda. Sedangkan untuk promosi, harga produk akan lebih murah apabila biaya promosi produk tidak hanya 
dibebankan kepada perusahaan, tetapi juga kepada pengecer.

f. Biaya memproduksi atau membeli produk. Seorang pengusaha perlu mempertimbangkan biaya-biaya dalam produksi dan perubahan yang terjadi dalam kuantitasproduksi apabila ingin dapat menetapkan harga secara efektif.

Senada dengan hal tersebut diatas, dalam penelitian ini menunjukan bahwa variabel Harga berpengaruh positif dan signifikan dalam mempengaruhi minat beli konsumen atau calon konsumen untuk dapat melakukan pembelian unit perumahan di Kota Citra Graha, hal ini dapat dibuktikan dengan tingkat probabilitas lebih dari 0,05 atau kurang dari 5\%. Dari hasil rangkuman nilai $\mathrm{T}$ signifikan pada tabel 5.9 terlihat bahwa, Variabel X2 (Harga) nilai signifikan T lebih besar dari $5 \%$ yaitu 6.348 dengan angka sig. 0.000. Jadi variabel X2 signifikan dalam mempengaruhi $\mathrm{Y}$ (Minat) atau $\mathrm{H}_{0}$ ditolak dan $\mathrm{H}_{\mathrm{a}}$ diterima.

\section{Kesimpulan Dan Saran}

Dari hasil analisis yang dilakukan, diperoleh bahwa variabel kualitas dan harga secara siginifikan berpengaruh baik secara parsial maupun simultan dan perubahannya berubah searah dengan minat beli konsumen atau calon konsumen untuk dapat melakukan pembelian unit perumahan di Kota Citra Graha. Artinya jika tingkat pengaruh kedua variabel dapat dirasakan oleh para konsumen atau calon konsumen makin tinggi, maka mengakibatkan makin tinggi juga tingkat minatnya untuk dapat melakukan pembelian unit perumahan di Kota Citra Graha.

Untuk melihat dominasi pengaruh dari variabel bebas terhadap variabel terikatnya, maka bisa dilihat koefisien beta (koefisien regresi baku). Nilai koefisien regresi baku antar variabel bebas dapat dibandingkan, karena nilainya telah distandarisasi sehingga variabel bebas yakni Variabel Kualitas (X1) dan Harga (X2) memiliki koefisien regresi baku yang lebih besar, berarti akan memberi pengaruh yang lebih besar pula pada variabel terikatnya.

Implikasi hasil uji $\mathrm{F}$ bagi perusahaan dalam hal ini adalah pihak manajemen perumahan Kota Citra Graha jika ingin meningkatkan tingkat minat Konsumen atau calon konsumen untuk dapat melakukan pembelian unit perumahan di Kota Citra Graha maka perlu menekankan pada kedua faktor tersebut yaitu berturut-turut Kualitas (X1) dan Harga (X2). Hal ini harus dilakukan secara terus menerus (continues improvement) dalam usaha untuk meningkatkan tingkat minat konsumen.

Untuk mendukung keterangan diatas dapat juga kita lihat hasil $\mathrm{R}^{2}$ (Koefisien Determinasi) Regresi yaitu dari hasil uji menunjukan nilai 0.406 atau $40.6 \%$. Hal ini dapat diartikan bahwa sebanyak $40.6 \%$ Tingkat minat beli konsumen akan pembelian unit perumahan di Kota Citra Graha. Sedangkan sisanya sebesar 59.4\% dijelaskan oleh variabel lain diluar variabel yang dapat mempengaruhi terhadap minat beli konsumen akan pembelian unit perumahan di Kota Citra Graha.

\section{DAFTAR USTAKA}

Asri, Marwan. 1991. Marketing. Yogyakarta: UPP AMP YKPN.

Angel, James F. Roger D. Black Well, Paviw, Miniard,1994. Perilaku Konsumen, Edisi Keenam, Jilid I. Jakarta. PT. Bina Rupa Aksara.

Alma, Buchari, 2004, Manajemen Pemasaran Dan Pemasaran Jasa, edisi revisi, cetakan kelima, Penerbit : Alfabeta, Bandung.

Assauri, Sofjan. 2004. Manajeman Pemasaran. Raja Grafindo Persada. Jakarta. 
Basu Swastha dan Irawan. 2001. Sumarwan, Ujang, 2003, Perilaku Manajemen Pemasaran Modern. Yogyakarta:

FE UGM.

Cannon, Joseph, dkk. 2009. Pemasaran Dasar. Jakarta: Salemba Empat.

Ghozali, Imam. 2007. Aplikasi Analisis Multivariate dengan Program SPSS Edisi 4. Semarang: Badan Penerbit Universitas Diponegoro.

Hadi, Sutrisno. 2000. Metodologi Research. Yogyakarta: Andi Yogyakarta.

J. Supranto, 1997. Pengukuran Tingkat Kepuasan Pelanggan, Jakarta: PT. Rineka Cipta.

Juwandi, Hendy Irawan. 2004. Kepuasan Pelayanan Jasa. Erlangga. Jakarta.

Kotler, Phillip. 1996. Principlesof Marketing. London, New York: Prentice Hall.

Kotler, Phillip. 2008. Manajemen Pemasaran Edisi Keenam Jilid 2. Jakarta: Erlangga.

Kotler, Philip dan Armstrong Gary. 2008. Prinsip-Prinsip Pemasaran Edisi Kedua Belas Jilid 2. Jakarta: Erlangga.

Kotler, Phillip dan Keller, Kevin. 2009. Manajemen Pemasaran Edisi Ketiga Belas Jilid 1. Jakarta: Erlangga.

Porter, M. E. (1980), Competitive Strategy : Technigues For Analizing Industries and Competitors, The Free Press, New York

Peter, Paul danJerry C. Olson. 2000. Perilaku Konsumen dan Strategi Pemasaran.
(Alih
Bahasa
Damos

Sihombiing).Jakarta: Elrlangga.

Swastha, Basu dan T. Hani Handoko, 2000, Manajemen Pemasaran, Analisa Perilaku Konsumen, edisi pertama, cetakan ketiga, Penerbit : BPFE, Yogyakarta. 